\title{
Biochemical Properties of Mercuric Reductase from Local Isolate of Bacillus sp for Bioremediation Agent
}

\author{
Purkan Purkan $^{1 *}$, Yuliana Firdausi Nuzulla ${ }^{1}$, Sofijan Hadi ${ }^{1}$, Endang Triwahyu Prasetyawati ${ }^{2}$ \\ ${ }^{1}$ Biochemistry Division, Chemistry Department, Faculty of Science and Technology, \\ Airlangga University, Kampus C Jl Mulyorejo Surabaya, Indonesia \\ ${ }^{2}$ Agriculture Faculty, UPN Veteran, East Java-Indonesia \\ *email: purkan@fst.unair.ac.id
}

Received October 06, 2017; Accepted November 26, 2017; Available online November 30, 2017

\begin{abstract}
Mercuric reductase is the important enzyme which catalyzes a reduction of a toxic $\mathrm{Hg}^{2+}$ to non-toxic $\mathrm{Hg}^{0}$. The enzyme which has been potentially used as mercury bioremediation agent is produced by mercury resistant bacteria. These research aims are to determinate the resistance level of a local Bacillus sp to $\mathrm{HgCl}_{2}$ in media, to determine the mercuric reductase activity from the bacteria, and to determine the biochemical properties of the mercuric reductase. The Bacillus sp was grown in the Nutrient Broth media with various of $0 ; 20 ; 40 ; 60 ; 120$; and $160 \mu \mathrm{M} \mathrm{HgCl}_{2}$ to know the response of the bacteria against mercury, The cell growth of Bacillus sp was measured by optical density (OD) method of at $\lambda 600 \mathrm{~nm}$. The mercuric reductase activity was assayed in the solution of MRA (Mercury Reductase Assay), then the oxidized NADPH was observed by the spectrophotometry method at $\lambda 340 \mathrm{~nm}$. The result showed that the Bacillus $s p$ has been resistant to media containing mercury at $120 \mu \mathrm{M}$, but the microbial growth was decreased by $50 \%$ in media containing mercury $80 \mu \mathrm{M}$. The Bacillus sp could produce highly the mercuric reductase enzyme at 16 hours of growth time with enzyme activity as $0.574 \mathrm{Unit} / \mu \mathrm{g}$. The mercuric reductase from the bacteria has an optimum activity at $\mathrm{pH} 6$ and temperature $37^{\circ} \mathrm{C}$
\end{abstract}

Key words: Bacillus sp., mercuric reductase, bioremediation

\section{INTRODUCTION}

The development of industry in Indonesia is so rapid, then it followed by the addition of the amount of waste in the environment. Waste on environmental pollution contains toxic chemicals, one of which is heavy metal mercury $(\mathrm{Hg})$. The Government of Indonesia gives the mercury contamination threshold through Government Regulation of Republic of Indonesia number 82 the year 2001 for group I equal to $0.001 \mathrm{mg} / \mathrm{L}$, group II is 0.002 $\mathrm{mg} / \mathrm{L}$, group III is $0.002 \mathrm{mg} / \mathrm{L}$, while group IV is $0.005 \mathrm{mg} / \mathrm{L}$. Various methods are used to reduce the mercury contamination from nature. One of them with the method of bioremediation which represent as a technique using microorganisms to reduce pollutants from environments. The mercury resistant bacteria could growth well on the medium containing mercury more than $5 \mathrm{mg} / \mathrm{L}$ (De Jaysankar, Ramaiah, Mesquita, and Verlekar, 2003; Adriana, Michele, Michele, Josino, and Ana, 2008). The potency of the bacteria is important to be used as a microbial bioremediation agent to clean mercury contaminant in environments.
The ability of mercury-resistant bacteria can produce mercuric reductase which is an enzyme with activity in the reducing of $\mathrm{Hg}^{2+}$ to $\mathrm{Hg}^{0}$. This case facilitates the bacteria can survive to a toxic of ionic mercury $\left(\mathrm{Hg}^{2+}\right)$ in the (Nascimento, and Charton-Souza, 2003). Mercury-resistant bacteria can reduce mercury ions by involving mercuric reductase enzymes and NADPH via the redox reaction equation (Figure 1).

Some bacteria have been reported to produce mercuric reductase enzymes are E. coli, Acinetobacter,

Enterobacteriaceae, Pseudomonas sp., Xanthomonas sp., Bacillus sp., and Staphylococcus sp. (Zeroual, Moutaouakkil, Dzairi, Talbi, and Chung,, 2003). The Bacillus sp. has been isolated from Malang agricultural, but its potency has been unknown to produce the mercuric reductase enzyme. The research was developed to observe the mercury resistance level of the bacteria. In addition to detect the properties of mercuric reductase enzyme which is produced by the bacteria as a bioremediation agent to reduce mercury waste. 


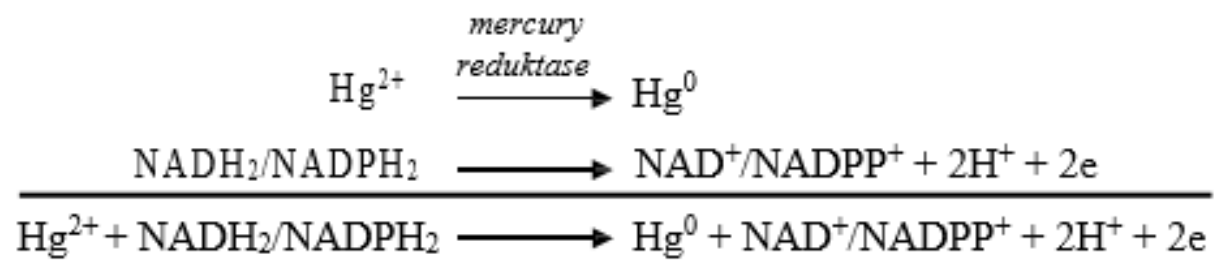

Figure 1. Redox reaction mercury ions by involving mercuric reductase enzymes and NADP

According to the classification of enzymes internationally, mercuric reductase is an enzyme in the class of oxidoreductase that is an enzyme that catalyzes the electron transfer reaction (Lehninger, 2004). There are four types of enzymatic mechanisms associated with mercuric reductase, namely: (1) reducing $\mathrm{Hg}^{2+}$ to $\mathrm{Hg}^{0}$; (2) break down the organomercury compound (including $\mathrm{MeHg}^{+}$), which results in the form $\mathrm{Hg} 0$; (3) methylation of $\mathrm{Hg}^{2+}$, and oxidation of $\mathrm{Hg}^{0}$ to $\mathrm{Hg}^{2+}$. The process of reduction of $\mathrm{Hg}^{2+}$ by mercuric reductase is done by coenzyme NADPH and NADH (Barkay, Miller, and Summer, 2003; Møller, Barkay, Hansen, Norman, and

Hansen, 2014. The mechanism of action of mercuric reductase is carried out by the transfer of electrons from NADPH via FAD to reduce the active part of the cysteine. The active cysteine is converted into two shaped cysteine forms of $\mathrm{SH}$ function. One of the forms of cysteine forms a complex transfer charge with $\mathrm{FAD}$, and the active part of cysteine reduces $\mathrm{Hg}^{2+}$ to C-terminal cysteine, forming $\mathrm{Hg}^{0}$ (Lian, Guo, Riccardi, Dong, and Parks, 2014); Freedman, Chengsheng, and Barkay, 2012).

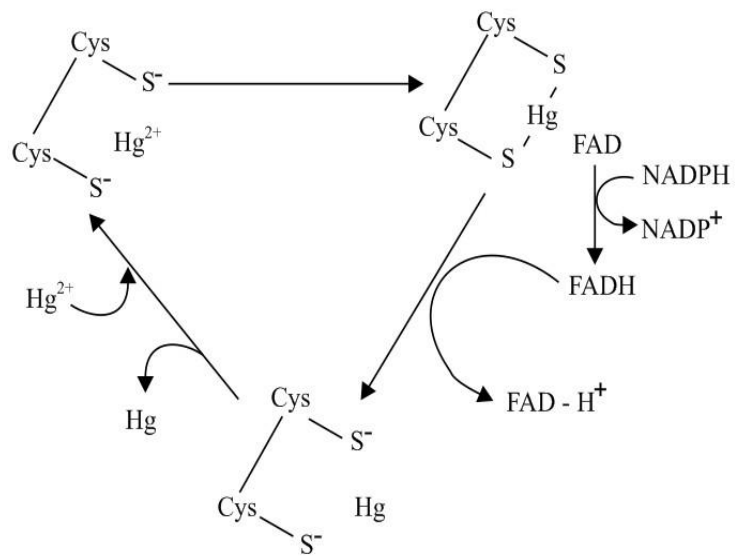

Figure 2. Mechanism of mercuric reductase action (Lian, et. al.,2014)

\section{EXPERIMENTAL SECTION}

\section{Chemicals and Instruments}

Bacillus sp. used is obtained from the agricultural land of Malang. Nutrient Agar (NA) and Nutrient Broth (NB), $\mathrm{HgCl}_{2}$, EDTA,
NADPH, $\quad \beta$-Mercaptoetanol, $\quad \mathrm{MgSO}_{4}$, $\mathrm{CH}_{3} \mathrm{COONa}, \quad \mathrm{CH}_{3} \mathrm{COOH}, \quad \mathrm{Na}_{2} \mathrm{HPO}_{4}$ and $\mathrm{NaH}_{2} \mathrm{PO}_{4}$ growth medium. The instrument used in this research are autoclave, micropipette, $\mathrm{pH}$ meter, thermometer, laboratory commonly used glass equipment, UV-Vis spectrophotometer Shimadzu UV-1800, batch ultrasonicator, shaker, incubator, Laminar Air Flow Kottermann 8580, centrifuge (Beckman 201).

\section{Procedures \\ Culturing of Bacteria}

The Bacillus sp.was grown on Nutrient Agar (NA) media composed by $0.3 \%$ (b/v) Beef extract and $0.5 \%(\mathrm{~b} / \mathrm{v})$ peptone, then incubated for 24 hours at $37{ }^{\circ} \mathrm{C}$ to achieve optical density (OD) 0.1 at $\lambda 600 \mathrm{~nm}$ and then used as a starter.

\section{The $\mathbf{H g C l}_{2}$ Resistance Assay}

One percent (v/v) of starter of Bacillus $s p$. cultured in $20 \mathrm{~mL}$ Nutrient Broth (NB) medium containing $\mathrm{HgCl}_{2}$ in various concentration of $0 ; 20 ; 40 ; 60 ; 120 ;$ and 160 $\mu \mathrm{M}$. The cultures then incubated at $37{ }^{\circ} \mathrm{C}$ with shaking at $150 \mathrm{rpm}$ for various time of $0,8,16$, 24 , and 48 hours. The grown of bacterial cells were calculated by the method of turbidimetry at $\lambda 600 \mathrm{~nm}$.

\section{Preparation of Growth Curve}

One percent $(\mathrm{v} / \mathrm{v})$ of Bacillus $s p$ was cultured in $50 \mathrm{~mL}$ of Nutrient Broth (NB) medium without $\mathrm{HgCl}_{2}$ and with $\mathrm{HgCl}_{2}$. Subsequently the culture was incubated at 37 ${ }^{\circ} \mathrm{C}$ at a rate of $150 \mathrm{rpm}$ with shaking. Every four hours of cell suspension was measured OD at $\lambda 600 \mathrm{~nm}$, then plot the absorbance value to be a graphic

\section{Isolation of Mercury Reductase Enzymes}

The cell suspension obtained during cells harvesting was centrifuged at $9000 \mathrm{rpm}, 4$ ${ }^{\circ} \mathrm{C}$ for $20 \mathrm{~min}$. The supernatant was discarded, then the cell was resuspended in $30 \mathrm{~mL}$ buffer Na-phosphate $\mathrm{pH}$ 7. The cell suspension was then sonicated for 60 seconds with an ultrasonicator batch $(2 \%$ power, $50 \mathrm{~Hz}$ frequency). After that, it was centrifuged at a 
rate of $9000 \mathrm{rpm}$ for $30 \mathrm{~min}$ at $4{ }^{\circ} \mathrm{C}$. The supernatant is transferred into a clean and sterile bottle carefully. The resulting supernatant is a crude extract of the mercuric reductase enzyme (Lusiana, 2014; Kannan, and Krishnamoorthy, 2006).

\section{Protein Content Assay}

Determination of protein content is done by using Bradford method. The test was performed by adding $80 \mu \mathrm{L}$ crude extract enzyme with $500 \mu \mathrm{L}$ of Bradford reagent into ten $\mathrm{mL}$ measuring flask and then adding with distilled water to the boundary marker, incubated at room temperature for 10 minutes. The protein content can be determined by the wavelength of $\lambda 595 \mathrm{~nm}$ (Bradford, 1976). The protein content can be determined by calculating based on the absorbance value of the sample entered into the BSA standard curve regression equation.

\section{Mercury Reductase Enzyme Activity Test}

Three $\mathrm{mL}$ of MRA (Mercury Reduction Assay) solution which composed by $50 \mathrm{mM}$ of $\mathrm{Na}_{3} \mathrm{PO}_{4}$ buffer (pH 7), $0.5 \mathrm{mM}$ EDTA, $0.2 \mathrm{mM}$ $\mathrm{MgSO}_{4}, 0.1 \% \quad(\mathrm{v} / \mathrm{v}) \quad \beta$-mercaptoethanol, 0.1 $\mathrm{mM}$ NADPH was reacted with $1 \mathrm{~mL} 80 \mu \mathrm{M}$ $\mathrm{HgCl}_{2}$ and $0.1 \mathrm{~mL}$ of crude enzyme, incubated at $37{ }^{\circ} \mathrm{C}$ for $15 \mathrm{~min}$, then residual of $\mathrm{NADPH}$ was measured at $\lambda 340 \mathrm{~nm}$. A unit of mercuric reductase is defined as the number of enzymes that oxidize $\mu \mathrm{M}$ NADPH per minute in experimental condition (Zeroual et al. 2003; Purkan, Nurmalyya, and Hadi, 2016)

\section{Determination of $\mathrm{pH}$ and temperature optimum of enzyme activity}

The mercuric reductase enzyme extract was assayed its activity at different $\mathrm{pH}$ and temperature. The $50 \mathrm{mM}$ sodium phosphate buffer was used to adjust $\mathrm{pH}$ 6-8. Whereas the $\mathrm{pH}$ five was adjusted with acetate buffer. The range temperature which used to optimize in the enzyme activity assay is $30,37,40$, and $45{ }^{\circ} \mathrm{C}$.

\section{RESULTS AND DISCUSSION}

\section{Resistance of Bacillus sp toward $\mathbf{H g C l}_{2}$}

The growth response of Bacillus $s p$ to mercury was measured by the turbidity test of bacterial culture in media containing $\mathrm{HgCl}_{2}$ at various concentration per time. Results of the growth response of Bacillus sp. without and in the presence of $\mathrm{HgCl}_{2}$ is presented in Figure 3 . The growth response on mercury resistance test showed that the Bacillus sp. has survived in mercury media until concentration of $80 \mu \mathrm{M}$. For the incubation time of $32 \mathrm{~h}$, the bacteria Bacillus sp is still able to survive well in media containing $80 \mu \mathrm{M} \mathrm{HgCl}_{2}$ compared with its growth in media without $\mathrm{HgCl}_{2}$.

\section{Growth Curve Bacillus sp}

The growth curve of mercury-resistant bacterial was observed in media without and with $\mathrm{HgCl}_{2}$ in concentration of $80 \mu \mathrm{M}$. The growth showed 4 phases which are the exponential phase or logarithmic phase, stationary phase and death phase (Figure 4).The lag phase or adaptation phase is shown at an incubation time of 0 to 8 hours. At an incubation time 8 hours to 24 hours growth begins to increase rapidly so that this phase is called logarithmic phase or exponential phase. Making the inoculum is very good if done in logarithmic phase. The stationary phase is shown at incubation time of 32 hours to 40 hours. In this phase the number of cell populations remains due to the number of cells growing equal to the number of dead cells (Pelczar, and Chan, 2010); Giovanella, Cabral, Bento, Gianello, \& Camargo, 2016; Waluyo, 2008). At incubation time of 44 hours, there is a decrease of OD (Optical Density) value so that at 44 hours incubation time is called death phase.

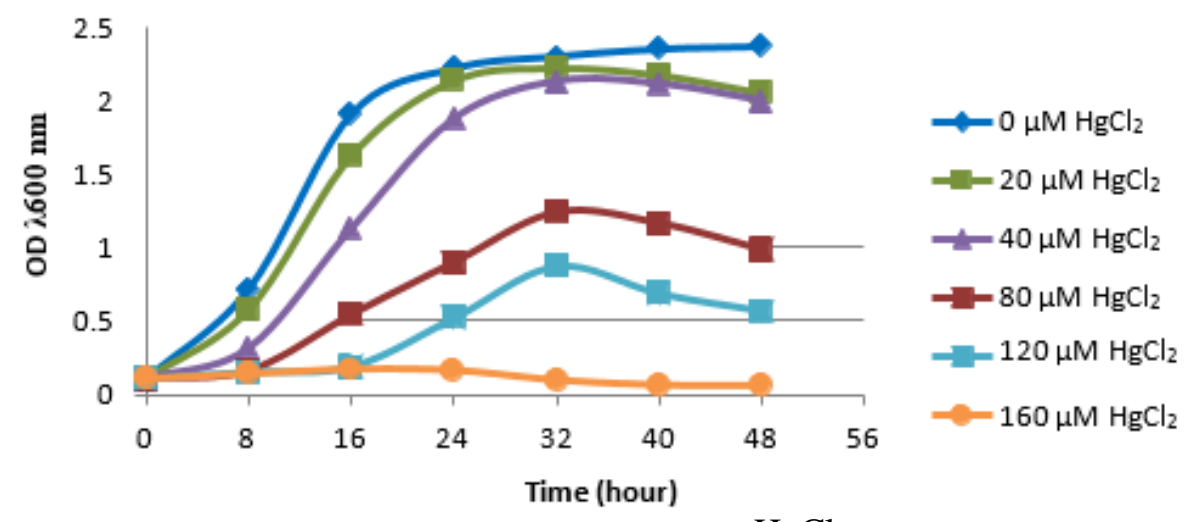

Figure 3. Growth response of Bacillus sp.toward $\mathrm{HgCl}_{2}$ at various concentration 


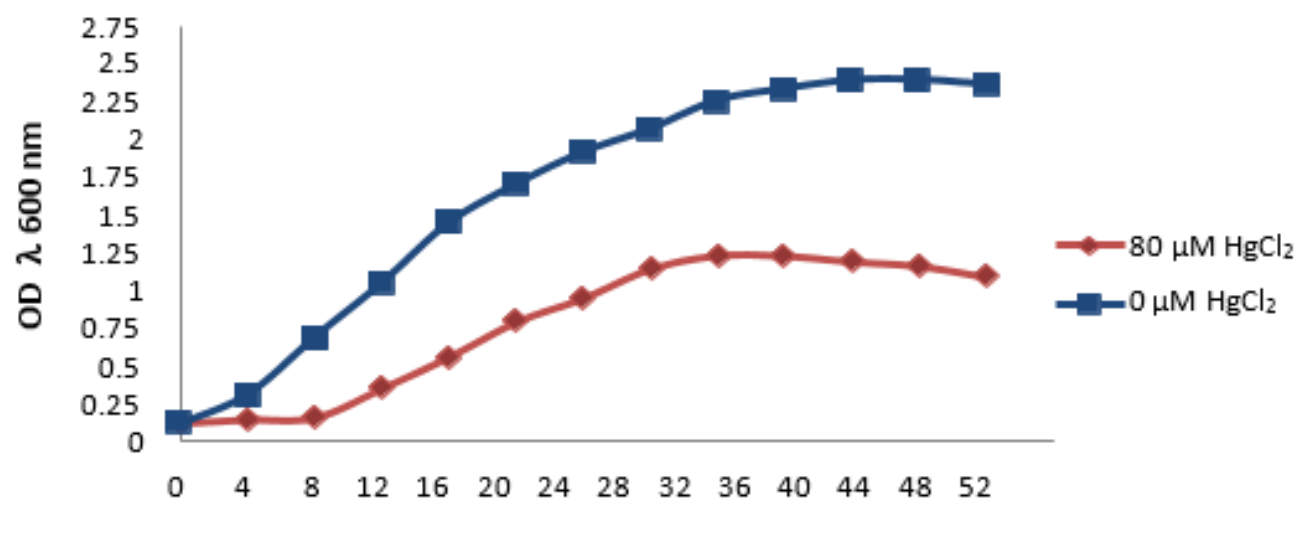

Time (hour)

Figure 4. The growth curve of Bacillus sp in media without $\mathrm{HgCl}_{2}$ and $80 \mu \mathrm{M} \mathrm{HgCl}_{2}$

\section{Enzyme Activity and Protein Content}

The isolation of enzyme and activity test were conducted to determine the ability of Bacillus $s p$ in producing mercuric reductase enzyme. The result of isolation of mercuric reductase enzyme then determined its protein level and used for enzyme activity test. Measurement of protein content was done by Bradford method. The Bradford test is used to measure the total protein concentration by colorimetry in a solution. The mercuric reductase activity test from Bacillus $s p$ shown in Figure 5.
The specific activity of an enzyme is obtained by dividing the activity of the enzyme with protein content. Based on the Figure 5 was known that the mercuric reductase enzyme from Bacillus sp local isolate had optimum activity at 16 hours harvesting time with a total activity of 0.5714 Units $\mu \mathrm{g}$ and $\mathrm{Hg}$ reduced by $16.8 \mu \mathrm{M}$. According to Marthiana (2010), the determination of optimum incubation time is intended to obtain the right time when enzyme activity is highest so that the best possible harvesting of enzymes can be done.

Table 1. Protein content in crude enzyme of mercuric reductase

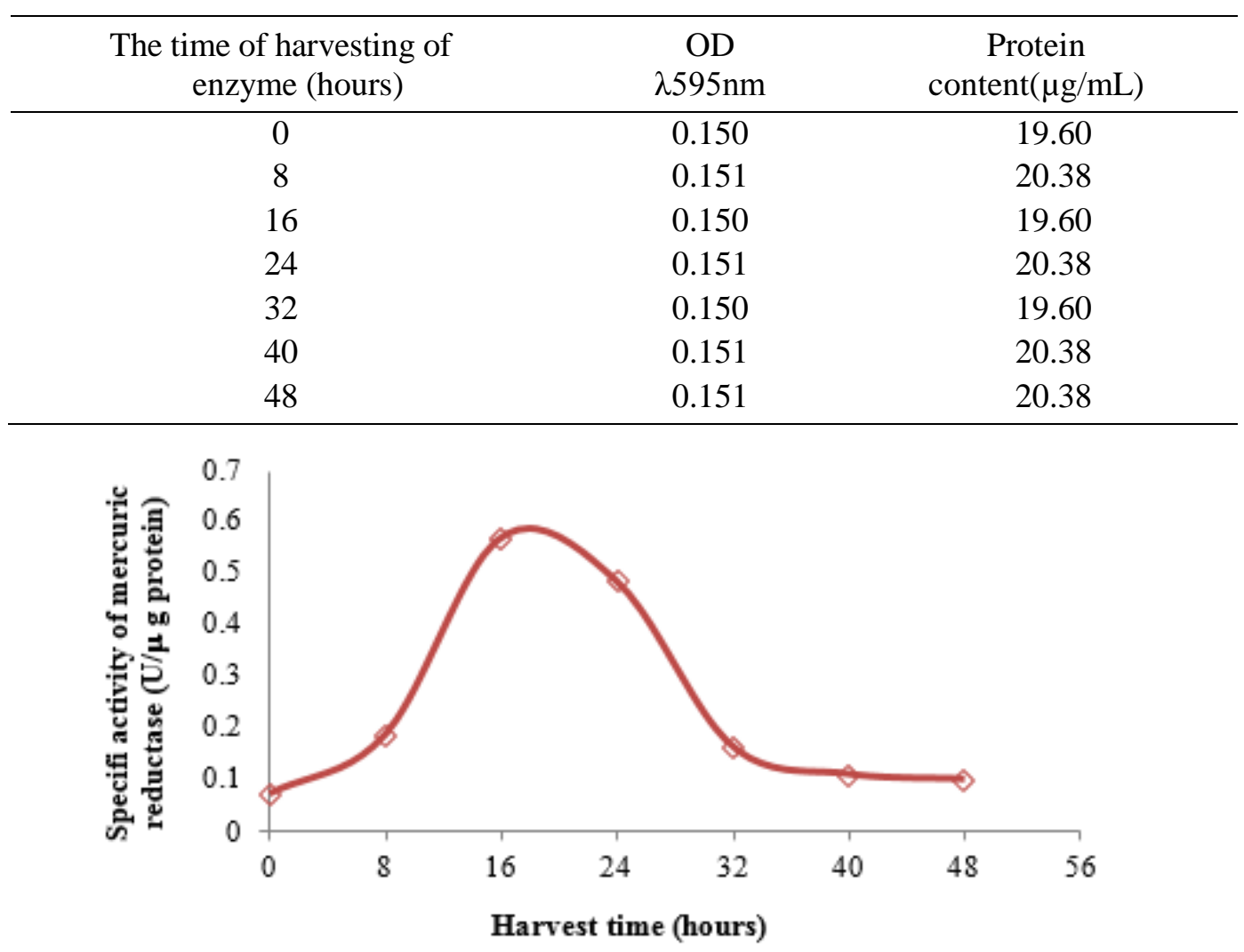

Figure 5. Effect of harvest time on specific activity of mercuric reductase enzyme 


\section{Characteristics of Mercury Reductase Enzymes The optimum pH}

The stability of the enzyme is influenced by many factors such as temperature, $\mathrm{pH}$, solvents, cofactors and the presence of surfactants (Kannan, and Krishnamoorthy, 2006). The enzyme shows maximum activity in the optimum $\mathrm{pH}$ range of the enzyme with high stability (Sulastri, 2002). Determination of $\mathrm{pH}$ of the enzyme mercuric reductase was determined by enzyme activity with a variation of $\mathrm{pH}(4,5,6,7$ and 8). The result data of $\mathrm{pH}$ effect on enzyme activity is shown that activity of mercuric reductase is optimum at $\mathrm{pH} 6$ (Figure 6).

At acidic $\mathrm{pH}$, the amount of enzyme mercuric reductase Bacillus sp.is low. The condition does not support for mercuric reductase enzyme to do a catalytic activity. While at a slightly acidic in the $\mathrm{pH} 6$, the enzyme activity is optimum with mercuric reductase activity of 12 Units / $\mathrm{mL}$, and there was $18 \mu \mathrm{M}$ reduced $\mathrm{Hg}$. High enzyme activity can occur due to the high specificity between the enzyme and the substrate, i.e., the functional group on the catalytic side is at the appropriate ionization. At $\mathrm{pH}$ seven enzyme activity also can be said good because the result of mercuric reductase activity equal to 11.2 Units / $\mathrm{mL}$, and there was obtained 16.8 $\mu \mathrm{M}$ reduced $\mathrm{Hg}$. At base $\mathrm{pH}$ that is $\mathrm{pH} 8$ activity of enzyme mercuric reductase decreasing that is equal to $8.5 \mathrm{Unit} / \mathrm{mL}$. This condition may cause a denaturation of the enzyme activity (Podjiadi and Supriyanti, 2005).

\section{Optimum temperature}

The effect of temperature on enzyme is related to the energy factor which needs to catalyze a reaction and also related to denaturation effect (Sulastri, 2002). The optimum temperature of mercuric reductase enzyme was determined in various temperature of 30, 37, 40, and $45{ }^{\circ} \mathrm{C}$. In the Figure 7 is shown that optimum activity of mercuric reductase is took placed at $37^{\circ} \mathrm{C}$.

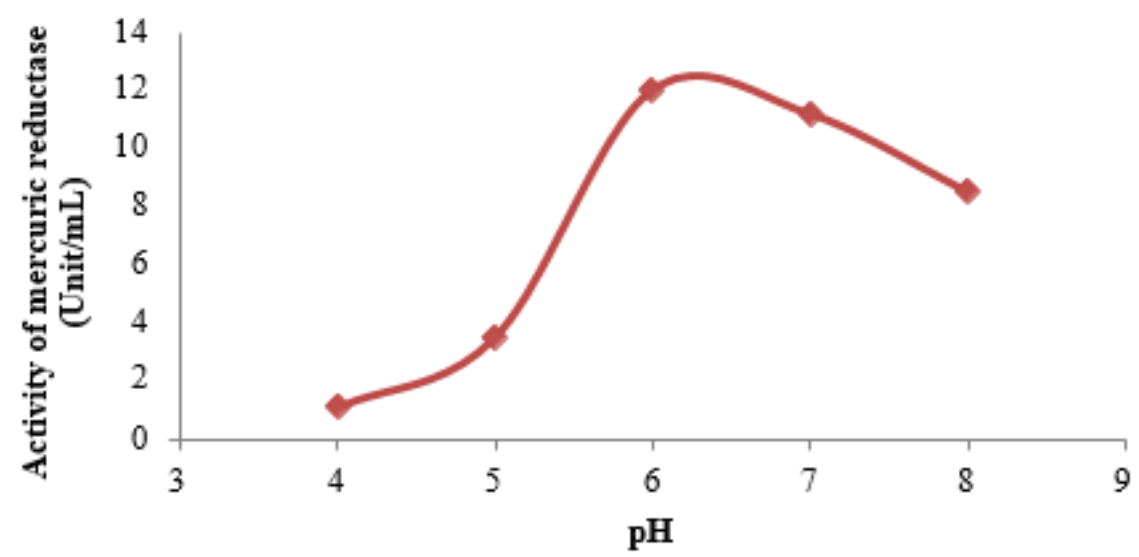

Figure 6. Effect of $\mathrm{pH}$ on the activity of mercuric reductase enzyme

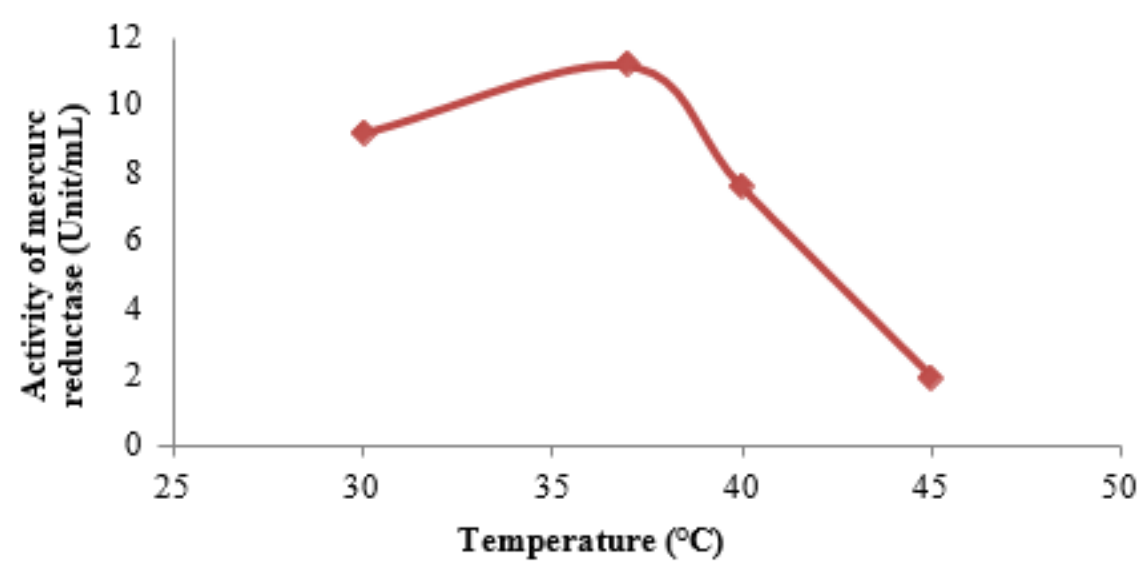

Figure 7. Effect of temperature on the activity of mercuric reductase enzyme 
The activity of mercuric reductase enzyme at $30{ }^{\circ} \mathrm{C}$ was low, which was 9.2 Units $/ \mathrm{mL}$ corresponding to reduced $\mathrm{Hg}$ form $13.8 \mu \mathrm{M}$. The energy in this condition might be insufficient to make reaction running, so then cause less optimal enzyme activity. The enzyme has optimum activity at $37{ }^{\circ} \mathrm{C}$ with 11.2 Units/mL and followed by $16.8 \mu \mathrm{M}$ reduced $\mathrm{Hg}$. At the optimum temperature the enzyme's energy is equal to the energy required to initiate the reaction between the enzyme and the substrate so that it proceeds well. At a temperature of $40{ }^{\circ} \mathrm{C}$ the activity of the enzyme decreased slightly by 7.6 Units $/ \mathrm{mL}$. This condition might create a denaturation effect, so the speed of enzyme reaction decreases up to four times. Based on the result, it is suggested to apply the local isolate of Bacillus $s p$ for bioremediation agent in the environment which contaminated with mercury in the setted temperature of $37^{\circ} \mathrm{C}$.

\section{CONCLUSION}

The Local isolate of Bacillus sp.exhibited a potential bioremediation agent and showed resistance level in $\mathrm{HgCl}_{2}$ up to $80 \mu \mathrm{M}$ in growth media. The bacteria could produce the mercuric reductase enzyme when it was grown until 16 hours of fermentation time, and exhibited a specific enzyme activity of 11.2 Units/mL.The mercuric reductase enzyme of Bacillus $s p$ had an optimum activity at $\mathrm{pH} 6$ and $37{ }^{\circ} \mathrm{C}$ respectively.

\section{REFERENCES}

Adriana S. M., Michele, S.J., Michele, L., Josino, C. M., Ana, L.L.F., and Paulo, R. G.B ., 2008, A conservative region of the mercuric reductase gene (mera) as a molecular marker of bacterial mercury resistance., Braz J Microbiol. 39(2): 307-310.

Bardford M.,M, 1976, A rapid and sensitive method for the quantitation of microorganisms quantities of protein in utilizing the principle of protein- dye binding, Anal, Biochem, 72:248-254

Barkay, T., Miller, S. M., and Summer, A. O., 2003, Bacterial Mercury Resistance from Atoms to Ecosystems, FEMS Microbiology Reviews, 27:255384

De Jaysankar, Ramaiah, N., Mesquita, A., and Verlekar, X.N., 2003, Tolerance to Various Toxicants by Marine Bacteria
Highly Resistant to Mercury. Marine

Biotechnology, 5:185-193

Freedman, Z., Chengsheng, Z., and Barkay, T., 2012, Mercury Resistance and Mercuric Reductase Activities and Expression among Chemotrophic Thermophilic Aquificae., Appl Environ Microbiol.; 78(18): 6568-6575.

Giovanella, P., Cabral, L., Bento, F. M., Gianello, C., \& Camargo, F. A. O. 2016. Mercury (II) removal by resistant bacterial isolates and mercuric (II) reductase activity in a new strain of Pseudomonas sp. B50A. New biotechnology, 33(1), 216-223.

Kannan, S. K., and Krishnamoorthy, R., 2006, Isolation of Mercury Resistant Bacteria and Influence of Abiotic Factors on Bioavailability of Mercury, Social of Total Enviroment, 367:341-353

Lehninger, A. L., 2004, Principles of Biochemistry, Fourth Ed, Worth Pub., New York, 1:345-350

Lian, P., Guo, H, B., Riccardi, D., Dong, A., Parks, J, M., Xu, Q., Pai, E. F., Miller, S. M., Wei, D., Q. Smith, J. C., and Guo, H., 2014, X-ray Structure of a $\mathrm{Hg}^{2+}$ Complex of Mercuric Reductase (MerA) and Quantum Mechanical/Molecular Mechanical Study of $\mathrm{Hg}^{2+}$ Transfer between the C-Terminal and Buried Catalytic Site Cysteine Pairs, Biochemistry, 53: 7211-7222

Lusiana S, 2014, Isolasi dan Karakterisasi Enzim Merkuri Reduktase dari Isolat Bakteri Pseudomonas sp., Skripsi, Surabaya,Universitas Airlangga, 12-14

Martharina, D., 2010, Karakterisasi Bakteri Asam Laktat Termofilik dari Sumber Air Panas Gunung Pancar, Bogor, Skripsi, Bogor, Institut Pertanian Bogor

Møller A.,K, Barkay T, Hansen MA, Norman A, Hansen LH, Sørensen SJ, Boyd ES, Kroer N., 2014, Mercuric reductase genes (merA) and mercury resistance plasmids in High Arctic snow, freshwater and sea-ice brine. FEMS Microbiol Ecol, 87(1):52-63.

Nascimento, A.M.A., and Charton-Souza, E., 2003, Operon mer: Bacterial Resistance to Mercury and Potential for Bioremediation od Contamined Environments, Journal Genetics and Molecular Research, http://funpecrp.com.br/gmr/year2003/vol 
1-2/sim0005_full_text.htm, Desember 2016

Purkan, Nurmalyya S., Hadi, S., 2016, Karakterisasi Enzim Merkuri Reduktase dari Isolat Bakteri Pseudomonas stutzeri, Skripsi, Surabaya, Universitas Airlangga

Pelczar, M.J., and Chan, E.C.S., 2010, DasarDasar Mikrobiologi, Jilid 1, Jakarta: UI Press, 132-142, 326,327

Podjiadi A., and Supriyanti. F.M.T., 2005, Dasar-Dasar Biokimia, edisi revisi, Jakarta: UI Press, 56-60
Sulastri, 2002, Uji Aktivitas Merkuri Reduktase dari Ekosistem Air Hitam Kalimantan Tengah, Tesis, IPB Bogor, 57-61

Waluyo, L., 2008, Teknik Metode Dasar Mikrobiologi, Universitas Muhammadiyah, Malang Press, 127-140 Zeroual, Y., Moutaouakkil, A., Dzairi, F. Z., Talbi, M., Chung, U. P., and Blaghen, M., 2003, Purification and Characterization of Cytosolic Mercury Reductase from Klebsiella pneumonia, Annals of Microbiology, 53:149-160 